\title{
Spatially varying complexity of bacterial and virus- like particle communities within an aquifer system
}

\author{
Ben Roudnew ${ }^{1, *}$, Trish J. Lavery ${ }^{1}$, Justin R. Seymour ${ }^{1,2}$, Renee J. Smith ${ }^{1}$, \\ James G. Mitchell ${ }^{1}$ \\ ${ }^{1}$ School of Biological Sciences, Flinders University, Adelaide, South Australia 5001, Australia \\ ${ }^{2}$ Plant Functional Biology and Climate Change Cluster (C3), University of Technology Sydney, Broadway, \\ New South Wales 2007, Australia
}

\begin{abstract}
Hydrological and geological heterogeneity in the subsurface can isolate groundwater bodies in an aquifer system and create hydrologically distinct aquifers overlying each other with varying amounts of water exchange and unknown amounts of biological exchange. The heterogeneous nature of these subsurface waters likely drives changes in groundwater microbiological parameters. In the present study, flow cytometry was used to examine the abundance and cytometrically defined subpopulation structure of bacteria and virus-like particles (VLPs) in 3 distinct, vertically stratified aquifer layers consisting of an unconfined aquifer, a confining layer and a confined aquifer. Despite total microbial abundances remaining constant, the composition of bacterial and VLP communities varied among the aquifer layers. Cytometrically defined subpopulations were defined by nucleic acid content and size and ranged from 1 bacterial and VLP subpopulation in the unconfined aquifer to 4 bacterial and 3 VLP subpopulations in the confined aquifer. This variability in the subpopulation assemblages is likely driven by a combination of hydrological heterogeneity and biological interactions. The results presented here indicate complexity in microbial communities in discrete aquifer layers that may be overlooked when reporting general abundances. Groundwater bacteria and VLPs appear to be a sensitive indicator of the biological dynamics of aquifer systems and may be used to identify heterogeneous water bodies and help distinguish individual aquifer layers in an aquifer system.
\end{abstract}

KEY WORDS: Bacteria · Virus-like particles · Groundwater · Aquifers · Flow cytometry · Abundance

Resale or republication not permitted without written consent of the publisher

\section{INTRODUCTION}

Microbes are found in almost all habitats on the planet, and form an essential part of ecosystem functioning as significant components of food webs and nutrient cycles (Azam et al. 1983, Goldscheider et al. 2006, Griebler \& Lueders 2009). Specifically, bacteria recycle nutrients through the biochemical degradation and transformation of dissolved organic matter and particulate organic matter (Azam et al. 1983). Viruses transform particulate organic matter into dissolved organic matter through the lysis of infected bacterial cells, which can indirectly affect bacterial species diversity and distribution (Fuhrman 1999). The role of bacteria and viruses in the functioning of ecosystems is increasingly recognised (Goldscheider et al. 2006); however, understanding of groundwater microbial interactions is still limited, due the complex nature of groundwater environments, which consist of solid and water substrate components.

Microbes experience temporal and spatial heterogeneity in groundwater systems, which may be attributed to numerous factors, including the physicochemical, geological and hydrological aspects of the aquifer system (Hancock et al. 2005). The temporal and spatial heterogeneity of groundwater habitats 
likely creates niches that allow some of the microbial consortia to outcompete rival species, resulting in a non-homogeneous distribution of microbial diversity in groundwater. The heterogeneous subsurface environment poses a challenge for ecologists interested in describing the bacterial and viral dynamics of groundwater ecosystems (Brockman \& Murray 1997). For example, complex and tortuous groundwater flow paths can influence microbial transport and the spread of pathogens in the subsurface (Fontes et al. 1991) and non-uniform distributions of bacteria in groundwater systems may influence rates of indigenous biodegradation or bioremediation activities (Brockman \& Murray 1997). Heterogeneity also provides challenges for the collection of samples that are representative of the aquifer under investigation.

The separation of an aquifer system into discrete aquifer layers is an example of geological heterogeneity and hydrological anisotropy isolating subsurface water bodies. For example, a confined aquifer may be vertically isolated from an unconfined aquifer and the water table due to the presence of a confining layer. As such, a single aquifer system may encompass distinct aquifer layers that, although they are in vertical spatial proximity, are hydrostratigraphically independent systems. Individual aquifer layers are often distinguished based on hydrogeological aspects, such as the geological composition, hydraulic conductivity, permeability and recharge, or based on physicochemical aspects such as the age or origin of the water (Cherry et al. 2004, Banks et al. 2007). The use of cased bores, such as piezometers, enables repeated sampling of different aquifer layers by allowing water to be directly sampled from predetermined depths.

A nested piezometer consisting of 6 individual piezometers installed at Ashbourne, South Australia, allowed for sampling from 3 distinct aquifer layers: a local shallow system (unconfined aquifer), a deeper fractured rock system (confined aquifer) and a less permeable confining layer that separates these 2 aquifers (Fig. 1). The lithological drill-logs of the Ashbourne site are reported in Harrington et al. (2004). Confirmation of the presence of the confining layer separating the confined and unconfined aquifer at the Ashbourne site was convincingly established by Banks et al. (2007) through the utilization of ${ }^{14} \mathrm{C}$ and chlorofluorocarbon (CFC-12) measurements. Water age in the shallow system was found to be 25 to $40 \mathrm{yr}$, while the maximum age of water in the deeper system was up to $1400 \mathrm{yr}$. Groundwater appeared to be younger at the $45 \mathrm{~m}$ depth than at $25 \mathrm{~m}$, which indicates distinct flow systems with separate sources of

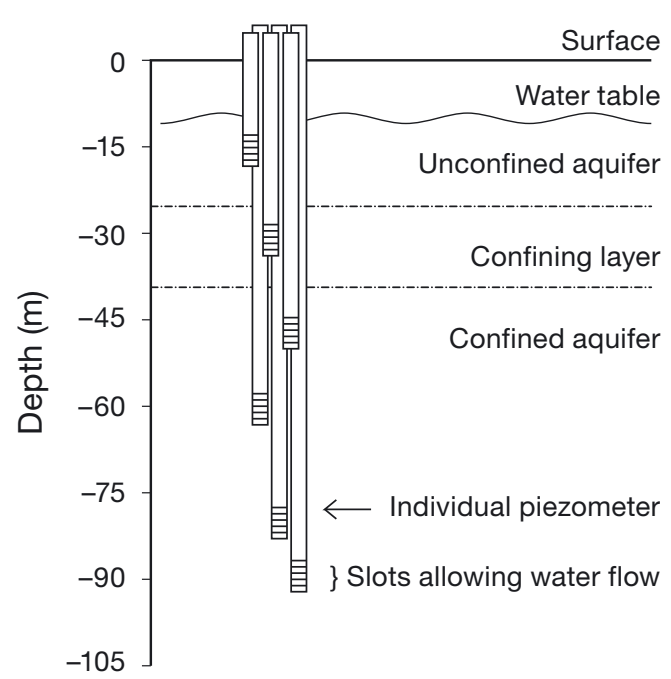

Fig. 1. Aquifer system at Ashbourne, South Australia: schematic representation of the nested piezometer consisting of six $50 \mathrm{~mm}$ diameter, individual PVC piezometers installed as a nest. The water table is approximately $8 \mathrm{~m}$ beneath the soil surface. Each piezometer had a slot/screen length of approximately $5 \mathrm{~m}$, at the following depths: 13-19 $\mathrm{m}$ (the unconfined aquifer), 29-34 $\mathrm{m}$ (the confining layer) and 42-47, 58-63, 79-84, 87-92 $\mathrm{m}$ (the confined aquifer)

recharge. Based on chloride mass balance and total dissolved solids (TDS) concentrations, the water shallower than $30 \mathrm{~m}$ is chemically distinct from deeper groundwater, which along with the CFC-12 data helped to confirm the presence of a confining layer between 25 and $40 \mathrm{~m}$ (Banks et al. 2007). The identification of the confining layer separating the unconfined and confined aquifer at Ashbourne allows for the investigation of hydrostratigraphically separated microbial consortia. However, measurement of the predicted low concentration of cells within this environment requires a sensitive and rapid method of analysis.

Flow cytometry (FCM) has been effectively used to enumerate bacterial and viral abundances from groundwater samples (Anneser et al. 2010, Leys et al. 2010, Roudnew et al. 2012, 2013, Smith et al. 2012). Viruses enumerated using FCM have not been specifically identified, morphologically or molecularly, as viruses and by convention are termed viruslike particles (VLPs) based on their relatively small size and lower nucleic acid content compared to bacteria (Marie et al. 1997, 1999, Brussaard et al. 2000). In addition to being a fast and efficient technique for enumerating bacteria and VLPs, FCM also carries the advantage of being able to discriminate discrete subpopulations of bacteria and VLPs based on cell/particle size and nucleic acid content (Marie et al. 1997, 1999, Brussaard et al. 2000). Bacterial sub- 
populations with higher nucleic acid content and, in some cases, a larger cell size indicate active bacterial cells most likely undergoing replication (Gasol \& del Giorgio 2000, Lebaron et al. 2001).

The fluorescent nucleic acid dye, SYBR Green I, has been developed to stain both DNA and RNA (Lebaron et al. 1998) and has been previously used to identify multiple VLP subpopulations in environmental samples (Patten et al. 2006, Seymour et al. 2007). Seymour et al. (2007) observed a significant correlation between bacteria and VLPs from a groundwater sinkhole, and it is likely that the majority of VLPs observed in the subsurface are bacteriophages (i.e. bacteria specific). Although the functional importance of VLP subpopulations remains to be determined, VLPs present in the system would likely influence bacterial turnover and nutrient cycling (Azam et al. 1983, Fuhrman 1999). Elucidating the presence of bacterial and VLP subpopulations in aquifers may contribute to an understanding of the heterogeneity of aquatic subsurface bacterial and VLP distributions; however, investigations of cytometrically defined bacterial and VLP subpopulations in aquifers are currently lacking.

A previous study at Ashbourne utilized FCM to compare bacterial and VLP abundances in purged aquifer water to unpurged water sampled from the slot depth of each piezometer (Roudnew et al. 2012). No significant difference was observed for bacteria, but VLP abundances were observed to significantly decrease in purged water. Bacteria and VLP concentrations were also found to vary with depth throughout the aquifer depth profile. In the present study we investigate the role of the individual aquifer layers on bacterial and VLP abundances and cytometrically defined subpopulation structures.

\section{MATERIALS AND METHODS}

\section{Sampling}

The Ashbourne site $\left(35^{\circ} 18^{\prime} \mathrm{S}, 138^{\circ} 46^{\prime} \mathrm{E}\right)$, South Australia, houses a $250 \mathrm{~mm}$ diameter hole, drilled into the Kanmantoo Group sediments in which six $50 \mathrm{~mm}$ diameter, piezometers were installed as a nest. The water table is approximately $8 \mathrm{~m}$ below the surface and slot depths are 13-19, 29-34, 42-47, $58-63,79-84$ and $87-92 \mathrm{~m}$ from the soil surface. The individual piezometers are open into an unconfined aquifer at $15 \mathrm{~m}$ depth, into a confined aquifer at 45 , 60,80 and $90 \mathrm{~m}$ depths and into a confining layer at $30 \mathrm{~m}$ depth that separates the unconfined and con- fined aquifers (Fig. 1). Each piezometer was purged using a 12 V Supertwister ${ }^{\circledR}$ submersible pump (EnviroEquip) for at least 3 bore volumes and until environmental parameters stabilised, prior to sampling nutrients, bacteria and VLPs. Environmental parameters of dissolved oxygen ( $\left.\mathrm{DO}, \mathrm{mg} \mathrm{l}^{-1}\right), \mathrm{pH}$, electrical conductivity $\left(\mathrm{EC}, \mathrm{mS} \mathrm{cm}^{-1}\right)$ and temperature $\left({ }^{\circ} \mathrm{C}\right.$ ) were measured using a calibrated Hach Hydrolab ${ }^{\circledR}$ MS5 (Aqualab Scientific) water quality sonde.

\section{Nutrient analysis}

Dissolved inorganic nutrients $(25 \mathrm{ml}$, in triplicate) were $0.45 \mu \mathrm{m}$ filtered (Whatman GF/C), placed on ice and analysed within $24 \mathrm{~h}$. Analyses were performed using a LF 2400 photometer (Aquaspex ${ }^{\circledR}$ ) according to standard colorimetric methods: ammonium $\left(\mathrm{NH}_{4}^{+}\right)$determined using the indophenol method, nitrate $\left(\mathrm{NO}_{3}{ }^{-}\right)$by diazotation/azo coupling using naphtyl-ethylenediamine after zinc reduction, nitrite $\left(\mathrm{NO}_{2}^{-}\right)$by diazotation/azo coupling using naphtyl-ethylenediamine and phosphate $\left(\mathrm{PO}_{4}{ }^{3-}\right)$ by ascorbic acid reduction using molybdenum blue.

\section{Preservation and preparation of bacteria and viruses}

Bacterial and VLP samples were preserved and prepared for FCM analysis following the protocols of Seymour et al. (2005), adapted from Marie et al. (1999). Triplicate, $1 \mathrm{ml}$ bacteria and VLP samples were immediately fixed in $1 \%$ glutaraldehyde, stored in the dark at $4^{\circ} \mathrm{C}$ for $15 \mathrm{~min}$, snap frozen in liquid nitrogen in the field and stored at $-80^{\circ} \mathrm{C}$. Prior to FCM analysis, samples were quick thawed in warm water and suspended at a 1:10 dilution in $0.02 \mu \mathrm{m}$ filtered TE buffer (10 mM Tris, $1 \mathrm{mM}$ EDTA, $\mathrm{pH}$ 8). Samples were stained with the fluorescent nucleic acid dye SYBR Green $I^{\circledR}$ (Molecular Probes) at a 1:20 000 dilution and vortexed for $30 \mathrm{~s}$. After the addition of SYBR Green all samples were kept in the dark until analysis.

\section{Flow cytometry analysis}

Samples were analysed on a FACS-Canto flow cytometer (Becton-Dickson) with the following settings: threshold $(530 / 30 ; 300 \mathrm{~V})$, forward angle light scatter $(285 \mathrm{~nm})$, side angle scatter $(580 \mathrm{~nm})$, green fluorescence $(530 \mathrm{~nm})$ orange fluorescence $(585 \mathrm{~nm})$ 
and red fluorescence $(670 \mathrm{~nm})$, with approximately 100000 events recorded for each sample. Phosphatebuffered saline solution was employed as a sheath fluid. Triplicate, $0.02 \mu \mathrm{m}$ filtered water samples were also prepared according to the above protocol so noise levels in the flow cytometer could be determined and subsequently subtracted from each sample. Fluorescent yellow, $1 \mu \mathrm{m}$ diameter beads (Molecular Probes) were added to each sample at approximately $10^{5}$ beads $\mathrm{ml}^{-1}$ and vortexed briefly immediately prior to analysis to normalise FCM parameters (Gasol \& del Giorgio 2000). Bead concentrations were determined by epifluorescence microscopy. Data were analysed using Win Midi 2.8 FCM analysis software (@ Joseph Trotter).

\section{Classification of subpopulations and statistical analysis}

Clustering of cells observed in each cytogram (Fig. 2) were gated and classified as distinct subpopulations based on SYBR Green fluorescence as an indicator of nucleic acid content, and side scatter as a proxy for cell size (Marie et al. 1997, 1999). The SYBR Green fluorescence on the $y$-axis and side scatter on the $x$-axis were plotted on 4 decade log scales to enable the plotting of bacteria and VLPs on the same cytogram with the size and fluorescence of the recorded events relative to each other. The $1 \mu \mathrm{m}$ fluorescent beads added to each sample to normalise FCM parameters were used as a standard for cell size and fluorescence. All bacteria $<1 \mu \mathrm{m}$ were enumerated, while VLPs were distinguished from bacteria based on their relatively small cell size and lower nucleic acid content according to previous work (Marie et al. 1997, 1999, Brussaard et al. 2000). Using cytogram dot plots (Fig. 2) along with density plots, contour plots and histograms of SYBR Green fluorescence individual VLP and bacterial subpopulations were gated when distinct clustering of cells/particles was observed. Fig. 3 was constructed to encompass the observed discrete bacterial and VLP subpopulations and enable subpopulations to be compared between depths in the aquifer system. Using Fig. 3, VLP subpopulations were classified as V1 to V3 and
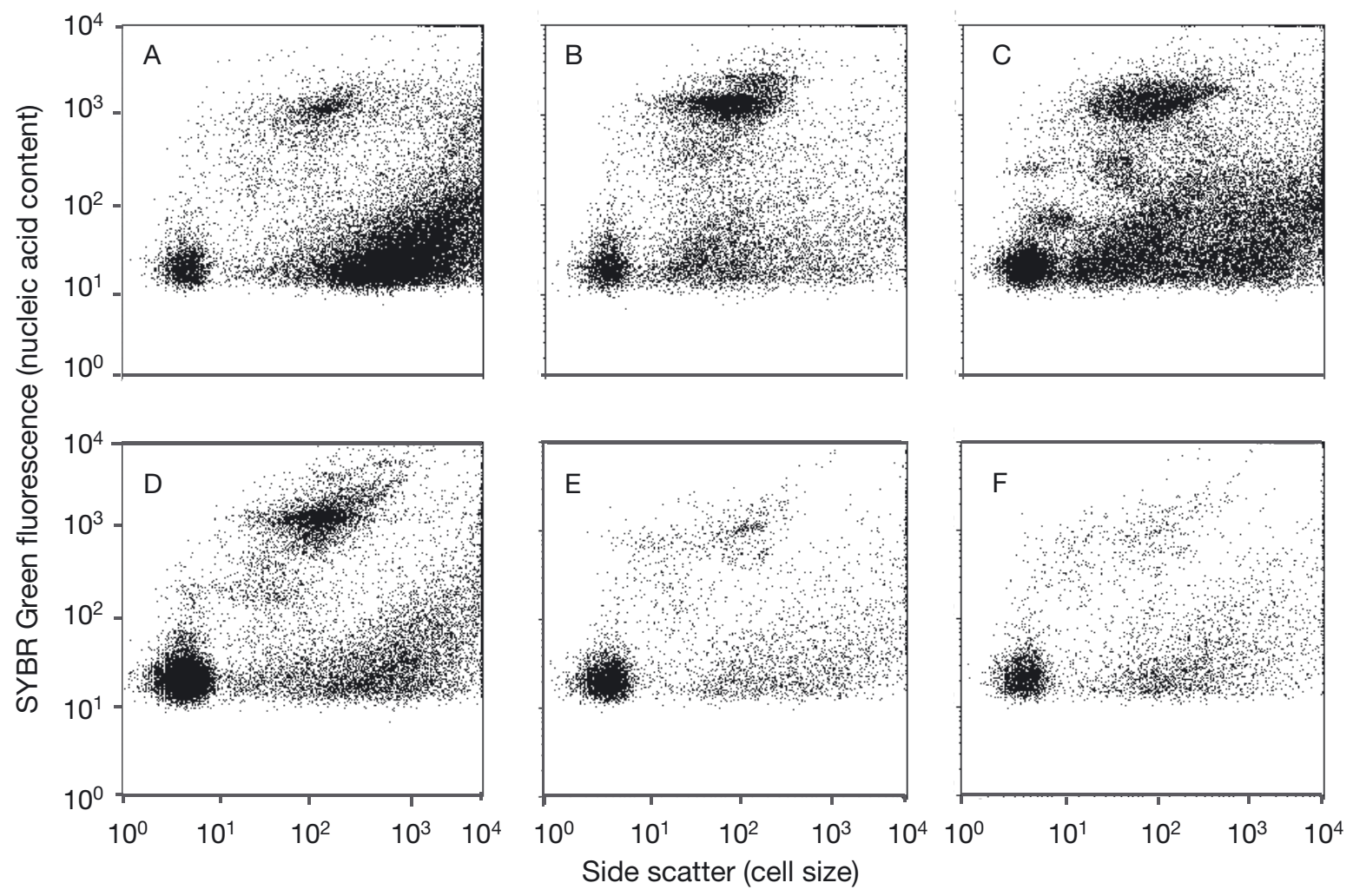

Fig. 2. Groundwater samples from aquifers at Ashbourne, South Australia: (A) the unconfined aquifer, (B) the confining layer and $(\mathrm{C}-\mathrm{F})$ the confined aquifer. SYBR Green fluorescence measures the amount of fluorescence given off when each particle/cell is excited by the laser and represents the nucleic acid content of each event (particle/cell). Side scatter (cell size) measures the reflection of the laser and is a proxy for cell/particle size 


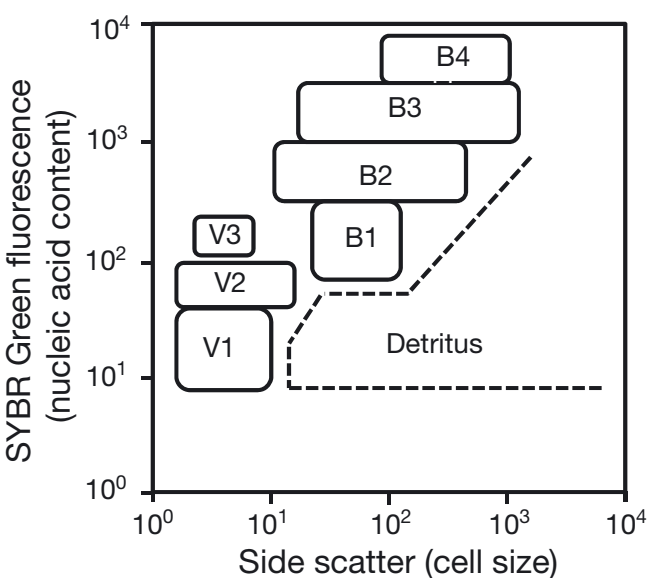

Fig. 3. Representation of gated subpopulations of bacteria (B1 to B4) and virus-like particles (VLPs; V1 to V3) observed throughout the depth profile in the aquifer system at Ashbourne, South Australia. Detritus represents noise, e.g. pieces of cells or free nucleic acid in the system. See Fig. 2 legend for explanation of $x$ - and $y$-axis labels

bacterial subpopulations were classified as B1 to B4. If the observed bacterial or VLP community on a cytogram recorded too few events for discrete subpopulations to be assigned, the entire bacterial or VLP population was categorised as bacterial subpopulation B3 or VLP subpopulation V1, i.e. the subpopulations found at all levels in the aquifer system (see 'Results and discussion'). Bacterial and VLP abundances among the aquifer layers were compared using a Kruskal-Wallis test. All statistical analyses were conducted on PASW ${ }^{\circledR}$ Statistics version 18 statistical software (๑ SPSS).

\section{RESULTS AND DISCUSSION}

\section{Microbiology of the aquifer system}

Bacterial abundances ranged from $6.3 \times 10^{3}$ to $3.0 \times$ $10^{5}$ cells ml ${ }^{-1}$ and were within the ranges reported in the literature (Griebler \& Lueders 2009, Anneser et al. 2010) (Fig. 4, Table 1). VLP abundances ranged from $4.8 \times 10^{4}$ to $8.8 \times 10^{5}$, with the lower range being slightly less than groundwater viral concentrations reported in the literature (Kyle et al. 2008) (Fig. 4, Table 1). No significant differences in total bacterial abundances $(p=0.146)$ and total VLP abundances $(p=0.453)$ were observed between aquifer layers (Fig. 4). However, changes in the distributions of cytometrically defined subpopulations were observed among the aquifer layers. Throughout the aquifer system, 4 discrete bacterial subpopulations,

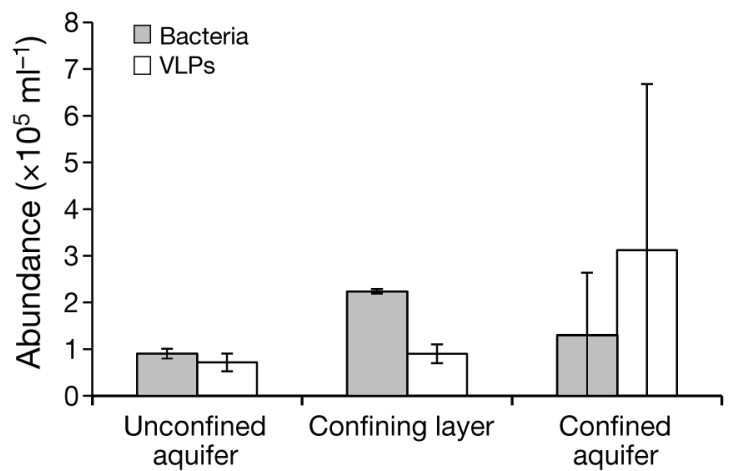

Fig. 4. Mean abundance of bacteria (cells $\mathrm{ml}^{-1}$ ) and viruslike particles (VLPs; particles $\mathrm{ml}^{-1}$ ), from the unconfined aquifer $(\mathrm{n}=3)$, confining layer $(\mathrm{n}=3)$ and confined aquifer $(\mathrm{n}=12)$. Error bars represent $\pm 1 \mathrm{SD}$

Table 1. Mean bacterial and virus-like particle (VLP) abundances, taken from the 6 piezometer depths $(n=3$ at each depth) at Ashbourne, South Australia. Numbers in parentheses represent $\pm 1 \mathrm{SD}$

\begin{tabular}{|c|c|c|}
\hline $\begin{array}{l}\text { Depth } \\
\text { (m) }\end{array}$ & $\begin{array}{l}\text { Bacteria } \\
\left(\text { cells ml }{ }^{-1}\right)\end{array}$ & $\begin{array}{c}\text { VLP } \\
\text { (particles } \mathrm{ml}^{-1} \text { ) }\end{array}$ \\
\hline 15 & $9.05 \times 10^{4}\left(1.03 \times 10^{4}\right)$ & $7.17 \times 10^{4}\left(1.92 \times 10^{4}\right)$ \\
\hline 30 & $2.24 \times 10^{5}\left(4.81 \times 10^{3}\right)$ & $9.00 \times 10^{4}\left(2.04 \times 10^{4}\right)$ \\
\hline 45 & $1.96 \times 10^{5}\left(3.99 \times 10^{3}\right)$ & $2.23 \times 10^{5}\left(2.80 \times 10^{4}\right)$ \\
\hline 60 & $3.01 \times 10^{5}\left(7.69 \times 10^{4}\right)$ & $8.83 \times 10^{5}\left(1.39 \times 10^{5}\right)$ \\
\hline 80 & $1.71 \times 10^{4}\left(5.06 \times 10^{3}\right)$ & $9.30 \times 10^{4}\left(2.22 \times 10^{3}\right)$ \\
\hline 90 & $6.35 \times 10^{3}\left(3.23 \times 10^{3}\right)$ & $4.82 \times 10^{4}\left(9.45 \times 10^{3}\right)$ \\
\hline
\end{tabular}

termed B1 to B4, and 3 VLP subpopulations, termed V1 to V3, based on size and nucleic acid content were identified (Figs. $2 \& 5$ ).

The observed changes in subpopulation dynamics may be due to biological processes, hydrogeochemical factors, or a combination of both. Biological processes such as bacterial-bacterial competition or bacterialviral interactions may create favourable conditions allowing certain subpopulations to thrive and outcompete other subpopulations. Alternatively, variations in flow rate and groundwater composition may allow for the creation of discrete niches, which could favour the survival of some microbial subpopulations.

\section{Homogeneous conditions}

The potentiometric head of an unconfined aquifer is the water table, and water recharges the aquifer by percolating in from the vertically adjacent surface. Thus, water contained in the unconfined aquifer at $15 \mathrm{~m}$ depth can be considered as having a single ori- 


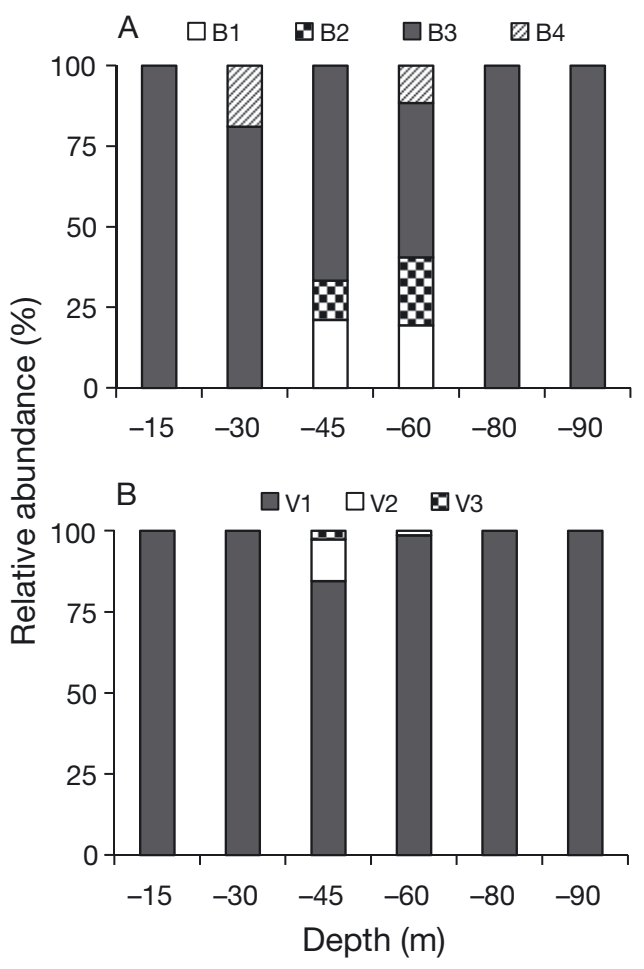

Fig. 5. Relative abundance (\%) of (A) bacterial and (B) viruslike particle (VLP) concentrations of cytometrically defined subpopulations (bacteria: B1 to B4; VLPs: V1 to V3), from the unconfined aquifer (15 $\mathrm{m}$ depth), confining layer $(30 \mathrm{~m})$ and confined aquifer $(45,60,80$ and $90 \mathrm{~m})(\mathrm{n}=3$ at each depth)

gin, the overlying surface. Only the B3 bacterial population and the V1 VLP population were present in the unconfined aquifer (Fig. 5). The only other area of the aquifer system that displays a single bacterial and VLP population is the deeper portion of the confined aquifer at 80 to $90 \mathrm{~m}$. Water in the deeper portion of the confined aquifer can also be characterised as water of single origin; as the age of water in this portion of the aquifer is $>1000 \mathrm{yr}$ (Banks et al. 2007), it is likely that the water composition is relatively homogeneous. The characteristic nature of homogeneous water would discourage the formation of niches (Cardinale 2011) and encourage less bacterial and VLP community complexity. Conditions within the unconfined aquifer and the deeper portion of the confined aquifer, where the source of water, the age of the water, the level of nutrients and the hydrological conditions are relatively homogeneous may encourage the domination of a single bacterial and a single VLP community population.

\section{Heterogeneous conditions}

Confining layers impede groundwater flow between aquifers (Ponzini et al. 1989) allowing for the concentration of contaminants and nutrients due to limited leaching into deeper groundwater systems. Table 2 displays evidence of salinity contamination and nutrients concentrating within the confining layer at Ashbourne. This trapping of contaminants and nutrients suggests that the confining layer may have a high level of physicochemical heterogeneity, whereby distinct niches can be formed and heterogeneous populations of microbes may be supported. Indeed, 2 separate bacterial subpopulations were observed, with the second bacterial subpopulation (B4) contributing $>10 \%$ of the total bacterial abundance (Fig. 5A). Subpopulation B4 consists of cells with high nucleic acid content, based on SYBR Green fluorescence. Previously, subpopulations showing relatively high nucleic acid content have been classified as active bacterial cells (Gasol \& del Giorgio 2000, Seymour et al. 2005, 2007, Patten et al. 2006). The high levels of inorganic nutrients represented by $1.40 \mathrm{mg} \mathrm{l}^{-1}$ of phosphate and $0.30 \mathrm{mg} \mathrm{l}^{-1}$ of nitrate that were observed in the confining layer are indicative of external nutrient inputs or internal cycling processes that perhaps sustain this active B4 bacterial population.

Bacterial and VLP concentrations were an order of magnitude greater at 45 and $60 \mathrm{~m}$ depths of the confined aquifer compared to the 80 and $90 \mathrm{~m}$ depths of the confined aquifer (Table 1). Unlike the single subpopulations observed in the deeper, homogeneous, portions of the confined aquifer, numerous bacterial and VLP subpopulations were observed throughout the shallower depths of the confined aquifer (Fig. 5). Bacteria at the $45 \mathrm{~m}$ depth was composed of 3 bacte-

Table 2. Environmental parameters of aquifers at Ashbourne, South Australia, measured at 1 depth in the unconfined aquifer $(n=3), 1$ depth in the confining layer $(\mathrm{n}=3)$ and 4 depths in the confined aquifer $(\mathrm{n}=12)$. Numbers in parentheses represent $\pm 1 \mathrm{SD}$

\begin{tabular}{|lcccr|}
\hline Parameter & Unit & $\begin{array}{c}\text { Unconfined } \\
\text { aquifer }\end{array}$ & $\begin{array}{c}\text { Confining } \\
\text { layer }\end{array}$ & $\begin{array}{c}\text { Confined } \\
\text { aquifer }\end{array}$ \\
\hline Temperature & ${ }^{\circ} \mathrm{C}$ & 16.56 & 16.68 & $17.39(0.59)$ \\
Electrical conductivity & $\mathrm{mS} \mathrm{cm}^{-1}$ & 3.42 & 13.75 & $2.01(0.23)$ \\
pH & & 6.66 & 10.85 & $7.19(0.60)$ \\
Dissolved oxygen & $\mathrm{mg} \mathrm{l}^{-1}$ & 0.24 & 0.36 & $0.21(0.10)$ \\
Ammonium & $\mathrm{mg} \mathrm{l}^{-1}$ & $0.12(0.05)$ & $0.42(0.02)$ & $0.19(0.26)$ \\
Nitrate & $\mathrm{mg} \mathrm{l}^{-1}$ & $0.20(0.10)$ & $0.30(0.26)$ & $0.20(0.10)$ \\
Nitrite & $\mathrm{mg} \mathrm{l}^{-1}$ & $0.01(0.00)$ & $0.01(0.00)$ & $0.01(0.01)$ \\
Phosphate & $\mathrm{mg} \mathrm{l}^{-1}$ & $0.37(0.06)$ & $1.40(0.75)$ & $0.30(0.25)$ \\
\hline
\end{tabular}


rial subpopulations, with the additional subpopulations B1 and B2 making up 21 and $12 \%$, respectively, of the total bacterial abundance. At the $60 \mathrm{~m}$ depth B1 and B2 made up 19 and $21 \%$ of the total bacterial abundance, respectively. Additionally, subpopulation B4 was observed at $60 \mathrm{~m}$ and contributed $12 \%$ of the total bacterial abundance. Multiple VLP subpopulations were also observed in the shallow portion of the confined aquifer, with V2 contributing to $13 \%$ of total VLP abundance and V3 contributing $3 \%$ at the $45 \mathrm{~m}$ depth, while at $60 \mathrm{~m}$ subpopulation V3 was not observed and V2 contributed to only $1 \%$ of the total VLP abundance.

It is possible that the physiochemical heterogeneity in the confining layer and the shallower portions of the confined aquifer provide the niche conditions necessary to support greater complexity in the bacterial community, which would sustain more potential host populations for VLPs and, in turn, greater complexity in the VLP community. Alternatively, VLPs may be driving community diversity. Viruses are known to selectively maintain diversity by infecting and lysing the dominant bacterial cells, a phenomenon termed 'kill the winner' (Thingstad \& Lignell 1997), thereby providing the opportunity for other bacterial cells to thrive and potentially promoting a more diverse assemblage of bacterial subpopulations. VLPs are known to enhance nutrient cycling through viral lysis by infecting bacteria and releasing particulate organic carbon into dissolved organic carbon, which can then be taken up by other bacterial cells (Azam et al. 1983). With additional nutrients recycled into the system, bacteria are able to reproduce and the number of active bacterial cells (i.e. bacterial subpopulation B4) would be expected to increase. Furthermore, lysing of bacterial cells would also create nutrient patchiness, which would lead to the heterogeneous conditions necessary for the proliferation of diverse assemblages of microbial consortia.

\section{Implications and conclusions}

FCM is effective for investigating the abundance and subpopulation dynamics of bacteria and viruses in aquifer systems and enables the investigation of community-wide microbial interactions. Bacterial communities with greater nucleic acid content are likely the dynamic members of the community, which actively respond to changes in predator pressure and nutrient availability (Kinner et al. 1998, Gasol at el. 1999). Size-selective predation has been observed in the marine environment (Gasol et al. 1999) and in studies of contaminated groundwater (Kinner et al. 1998) and such selective predation pressure may influence community dynamics and rates of bacterial driven contaminant degradation (Kinner et al. 1998). The present study shows that changes in aquifer hydrostratigraphy are associated with variations in bacterial and VLP subpopulation structures.

Hydrological heterogeneity in aquifer systems likely contributes to heterogeneity of bacterial and VLP subpopulations. Bacteria and VLPs appear to be a sensitive indicator of the biological dynamics of aquifer systems and potentially may be used to identify heterogeneous or homogeneous groundwater conditions and help distinguish hydrologically isolated or mixed aquifer layers and preferential flow paths in the subsurface. Larger bacterial cell sizes were observed in the hydrologically heterogeneous conditions of the confining layer and the shallow areas of the confined aquifer. These hydrologically heterogeneous areas may experience different levels of predation, bacterial turnover and nutrient cycling, compared to the hydrologically homogeneous regions as a result of the larger bacterial cell sizes observed. Future studies should consider the use of FCM in investigating subterranean microbial heterogeneity and efforts should be made to explore groundwater ecology based on a thorough understanding of the hydrogeomorphology of the system.

Acknowledgements. We thank T. Jeffries and K. Newton for valuable advice on the construction of this manuscript. We thank S. Bailey and E. Ng from the Flow Cytometry Unit of the Flinders Medical Centre, for providing technical support during the flow cytometry work. Funding was provided by the Australian Research Council (ARC) linkage grant LP0776478 and B.R. was a recipient of a Flinders University Research Scholarship.

\section{LITERATURE CITED}

Anneser B, Pilloni G, Bayer A, Lueders T, Griebler C, Einsiedl F, Richters L (2010) High resolution analysis of contaminated aquifer sediments and groundwaterWhat can be learned in terms of natural attenuation? Geomicrobiol J 27:130-142

Azam F, Fenchel T, Field J, Gray J, Meyer-Reil LA, Thingstad F (1983) The ecological role of water-column microbes in the sea. Mar Ecol Prog Ser 10:257-263

Banks E, Wilson T, Green G, Love A (2007) Groundwater recharge investigations in the Eastern Mount Lofty Ranges. DWLBC Report 2007/20, South Australia. Department of Water, Land and Biodiversity Conservation, Adelaide 
Brockman FJ, Murray CJ (1997) Subsurface microbiological heterogeneity: current knowledge, descriptive approaches and applications. FEMS Microbiol Rev 20: 231-247

Brussaard CPD, Marie D, Bratbak G (2000) Flow cytometric detection of viruses. J Virol Methods 85:175-182

Cardinale BJ (2011) Biodiversity improves water quality through niche partitioning. Nature 472:86-89

Cherry J, Parker B, Bradbury K, Eaton T, Gotkowitz M, Hart D, Borchardt M (2004) Role of aquitards in the protection of aquifers from contamination: a 'state of the science' report. Awwa Research Foundation, Denver, CO

Fontes DE, Mills AL, Hornberger GM, Herman JS (1991) Physical and chemical factors influencing transport of microorganisms through porous media. Appl Environ Microbiol 57:2473-2481

Fuhrman JA (1999) Marine viruses and their biogeochemical and ecological effects. Nature 399:541-548

Gasol JM, del Giorgio PA (2000) Using flow cytometry for counting natural planktonic bacteria and understanding the structure of planktonic bacterial communities. Sci Mar 64:197-224

Gasol JM, Zweifel UL, Peters F, Fuhrman JA, Hagström Å (1999) Significance of size and nucleic acid content heterogeneity as measured by flow cytometry in natural planktonic bacteria. Appl Environ Microbiol 65: 4475-4483

Goldscheider N, Hunkeler D, Rossi P (2006) Review: microbial biocenoses in pristine aquifers and an assessment of investigative methods. Hydrogeol J 14:926-941

Griebler C, Lueders T (2009) Microbial biodiversity in groundwater ecosystems. Freshw Biol 54:649-677

> Hancock PJ, Boulton AJ, Humphreys WF (2005) Aquifers and hyporheic zones: towards an ecological understanding of groundwater. Hydrogeol J 13:98-111

Harrington GA, James-Smith JM, Wohling D, van den Akker J (2004) Hydrogeological investigation of the Mount Lofty Ranges, progress report 5: Drilling phases 2.1 to 2.3: Research and monitoring wells at Scott Creek, Balhannah, Willunga Fault, Lobethal, Eden Valley and Ashbourne. DWLBC Report 2004/04, Department of Water, Land and Biodiversity Conservation, Adelaide

Kinner NE, Harvey RW, Blakeslee K, Novarino G, Meeker LD (1998) Size-selective predation on groundwater bacteria by nanoflagellates in an organic-contaminated aquifer. Appl Environ Microbiol 64:618-625

Kyle JE, Eydal HSC, Ferris FG, Pedersen K (2008) Viruses in granitic groundwater from 69 to $450 \mathrm{~m}$ depth of the Äspö Hard Rock Laboratory, Sweden. ISME J 2:571-574

Lebaron P, Parthuisot N, Catala P (1998) Comparison of blue nucleic acid dyes for flow cytometric enumeration of

Editorial responsibility: Hans-Georg Hoppe, Kiel, Germany bacteria in aquatic systems. Appl Environ Microbiol 64: 1725-1730

Lebaron P, Servais P, Agogué H, Courties C, Joux F (2001) Does the high nucleic acid content of individual bacterial cells allow us to discriminate between active cells and inactive cells in aquatic systems? Appl Environ Microbiol 67:1775-1782

- Leys R, Roudnew B, Watts CH (2010) Paroster extraordinarius sp. nov., a new groundwater diving beetle from the Flinders Ranges, with notes on other diving beetles from gravels in South Australia (Coleoptera: Dytiscidae). Aust J Entomol 49:66-72

Marie D, Partensky F, Jacquet S, Vaulot D (1997) Enumeration and cell cycle analysis of natural populations of marine picoplankton by flow cytometry using the nucleic acid stain SYBR Green I. Appl Environ Microbiol 63:186-193

> Marie D, Brussaard CPD, Thyrhaug R, Bratbak G, Vaulot D (1999) Enumeration of marine viruses in culture and natural samples by flow cytometry. Appl Environ Microbiol 65:45-52

> Patten NL, Seymour JR, Mitchell JG (2006) Flow cytometric analysis of virus-like particles and heterotrophic bacteria within coral-associated reef water. J Mar Biol Assoc UK 86:563-566

Ponzini G, Crosta G, Giudici M (1989) The hydrogeological role of an aquitard in preventing drinkable water well contamination: a case study. Environ Health Perspect 83:77-95

Roudnew B, Seymour JR, Jeffries TC, Lavery TJ, Smith RJ, Mitchell JG (2012) Bacterial and virus-like particle abundances in purged and unpurged groundwater depth profiles. Ground Water Monit Remediat 32:72-77

Roudnew B, Lavery TJ, Seymour JR, Jeffries TC, Mitchell JG (2013) Variability in bacteria and virus-like particle abundances during purging of unconfined aquifers. Ground Water (in press)

Seymour JR, Patten NL, Bourne DG, Mitchell JG (2005) Spatial dynamics of virus-like particles and heterotrophic bacteria within a shallow coral reef system. Mar Ecol Prog Ser 288:1-8

> Seymour JR, Humphreys W, Mitchell JG (2007) Stratification of the microbial community inhabiting an anchialine sinkhole. Aquat Microb Ecol 50:11-24

Smith RJ, Jeffries TC, Roudnew B, Fitch AJ and others (2012) Metagenomic comparison of microbial communities inhabiting confined and unconfined aquifer ecosystems. Environ Microbiol 14:240-253

Thingstad TF, Lignell R (1997) Theoretical models for the control of bacterial growth rate, abundance, diversity and carbon demand. Aquat Microb Ecol 13:19-27

Submitted: August 7, 2012; Accepted: January 21, 2013

Proofs received from author(s): March 10, 2013 